\title{
The Possible Involvement of Apoptotic Decay of Terminal Deoxynucleotidyl Transferase-Positive Lymphocytes in the Reutilization of the Extracellular DNA Fragments by Surrounding Living Cells
}

\begin{abstract}
Aleksei N. Shoutko
Department of Fundamental Research, Russian Scientific Center of Radiology and Surgical Technologies, Ministry of Health Care, RF, Saint-Petersburg, Russia

Email: shoutko@inbox.ru
\end{abstract}

How to cite this paper: Shoutko, A.N. (2021) The Possible Involvement of Apoptotic Decay of Terminal Deoxynucleotidyl Transferase-Positive Lymphocytes in the Reutilization of the Extracellular DNA Fragments by Surrounding Living Cells. Open Journal of Biophysics, 11, 371-382.

https://doi.org/10.4236/ojbiphy.2021.114014

Received: June 30, 2021

Accepted: August 15, 2021

Published: August 18, 2021

Copyright $\odot 2021$ by author(s) and Scientific Research Publishing Inc. This work is licensed under the Creative Commons Attribution International License (CC BY 4.0).

http://creativecommons.org/licenses/by/4.0/

\begin{abstract}
The migrating $\mathrm{TdT}^{+}$thymocytes can die in other tissues, promoting the surrounding cells' renewing likes holocrine secretion does. To clarify the role of TdT-enzyme for this function of progenitor lymphocytes, their extracellular media with its components included by living cells analyzed in vitro before and after in vivo irradiation of donor rats. The nucleoid with DNase-sensitive (free) DNA and TdT activity discovered in extracellular media conditioned preliminary by spontaneous apoptotic death of a minor part of the thymocyte's suspension in vitro. The penetration of labeled products of non-template synthesis with free DNA' primers from media into cells by pinocytosis confirmed by exogenous polymeric DNA marked artificially. The DNA penetration into cells follows an increase of the cell's viability and acceleration of spontaneous intracellular DNA-synthesis controlled with labeled thymidine uptake. Both phenomena are typical for either the lowest initial concentration of intact cells or their preliminary irradiation in vivo. The data point to possible involvement of apoptotic decay of $\mathrm{TdT}^{+}$cells in the reutilization of the extracellular DNA fragments for reparation/regeneration of surrounding living cells.
\end{abstract}

\section{Keywords}

Thymocytes, Apoptosis, Terminal Deoxynucleotidyl Transferase, Extracellular Activity, DNA Synthesis, Precursors, Reutilization 


\section{Introduction}

The fundamental property of circulating HSCs is their beneficial effect on cellular renewal and regeneration of tissues of various histotypes. The components of the lymphoid line of hematopoiesis, such as prolymphocytes of bone marrow and cortical thymocytes, may participate in this morphogenic effect of HSC, too. Only they have a specific marker Terminal deoxynucleotidyl Transferase (TdT). About $15 \%$ of the circulating $\mathrm{CD} 34^{+}$and $\mathrm{CD} 133^{+}$hematopoietic stem cells are $\mathrm{TdT}$ positive lymphoid progenitors [1]. Thus, they can participate in all processes of the morphogenesis provided by HSCs in peripheral organs and tissues. The enzyme does not require a template for activity. It catalyzes the incorporation of deoxynucleotides into the 3'-OH termini of single- or double-stranded DNA, using as a primer even short oligodeoxynucleotide of at least three bases. It is generally accepted only that the enzyme acts intracellularly, providing a variety of antigen receptors at the $\mathrm{V}(\mathrm{D}) \mathrm{J}$ junction of gene segment ( $\mathrm{N}$-region) by the random import of one of the four Deoxyribonucleotides Monophosphates (dNMP) in it. Therefore, enzyme TdT should belong to the group of intracellular potassium-dependent polymerases as all template-dependent DNA polymerases, losing activity tenfold in extracellular media with a physiological concentration of sodium ( $\approx 0.15 \mathrm{M} \mathrm{NaCl})$ [2]. However, the function of TdT may be more complex because it does not change in the range of $\mathrm{NaCl}$ content for plasma and extracellular media $0.14 \mathrm{M}$ and even increases unexpectedly up to $50 \%$ in the media with $0.22 \mathrm{M}$ of $\mathrm{Na}^{+}$[2]. Besides this extracellular property, TdT incorporates a dNMP into primer in the presence of divalent metal ions, for example, $\mathrm{Zn}^{2+}$, which basal concentrations level in extracellular media $(10 \mathrm{nM})$ is much higher than that in intracellular space (100 pM) [3]. Moreover, only TdT-positive lymphocytes lose their viability after blocking the 3'-OH primers in their DNA, though the blockers do not affect the viability of TdT-negative cells [4]. Eventually/Yet, antigenic stimulation of circulating T-cells can re-activate V(D)J recombination and re-express the gene $\mathrm{TdT}$, re-rejuvenating the mature cells [5]. The ability of TdT to polymerize both deoxy-deoxyribonucleotides, and ribonucleotides does not confirm its ultimate specificity for $\mathrm{V}(\mathrm{D}) \mathrm{J}$ recombination [6]. All these data indicate the possible function of the TdT-enzyme outside the cells is not in consideration until now [7]. On the other hand, the well-recognized existence of free DNA in extracellular media (exDNA) generally discusses in the context of horizontal gene transfer or, as a source of energy and nutrients to other cells after fragmentation by extracellular DNase, avoiding its possible interaction with extracellular polymerases, like TdT [8] [9].

The circulating cells with this unique enzyme do not yet find a place in the traditional pathophysiological schemes describing the health of mammals. Indeed, this fact seems to be an omission, taking into account the appearance of TdT too far from the bone marrow and thymus, where new vessels arise around artificial scaffolds [10]. In this article, we present data in vitro to support the expected trophic function of extracellular TdT. 


\section{Methods}

\subsection{Objects}

The source of thymocytes were glands of non-in-bread albino male rats (120 $130 \mathrm{~g}$ ) taken from animals before, 0.5 and 6 hours after total body X-irradiation in dose $8 \mathrm{~Gy}$ at a dose rate of $0.91 \mathrm{~Gy} / \mathrm{min}$, a $200 \mathrm{kV}$, a $15 \mathrm{ma}$, filters of $0.5 \mathrm{~mm}$ $\mathrm{Cu}$ and $1.0 \mathrm{~mm} \mathrm{Al}$. Thymocytes were isolated in iso-osmotic buffered Hanks Balanced Saline Solution (HBSS) and incubated at $37^{\circ} \mathrm{C}$ at different cells densities (from 2.5 to $23 \times 10^{7}$ cells $/ \mathrm{ml}$ ) and rotating two times per minute at angle 450 during $15-115$ minutes. Cell viability controls by trypan blue exclusion at dye's concentration of $0.1 \%$. For conditioning of extra Cellular Media (CM), 23 $\times 10^{7} \mathrm{cells} / \mathrm{ml}$ incubated 60 minutes. After centrifugation $(800 \times \mathrm{g}, 5 \mathrm{~min})$, supernatant adjusts to a $\mathrm{NaCl}$ concentration of $0.25 \mathrm{M}$ for an avoiding of template-dependent intracellular transcriptional activities (3 - 4 S DNA directed-DNA polymerase, $6-7$ polyribosyl adenylic acid-dependent DNA polymerase), and uses after second centrifugation $\left(1.2 \times 10^{5} \mathrm{~g}, 60 \mathrm{~min}\right)$ as the source of both natural the extracellular enzyme and the primers (further, conditioned media-CM).

\subsection{Analyses of CM with Diethyl-Aminoethyl (DEAE)-Cellulose Paper Chromatography}

DEAE-cellulose paper chromatography permits to divide CM onto six fractions which correspond to average molecular weight $6 \times 10^{2}(1), 2 \times 10^{3}(2), 5 \times 10^{4}$ (3), $1 \times 10^{5}(4), 1 \times 10^{6}(5)$, and $5 \times 10^{6}(6)$ Dalton of pure DNA [11]. The presence of free extracellular DNA in the fractions $\mathrm{CM}$ was evaluated by photometry in a quartz chamber with optical length $4 \mathrm{~cm}$ or $10 \mathrm{~cm}$, before and after treatment of the CM with DNase I (Merck; $25 \mu \mathrm{g} / \mathrm{mL}, 10$ minutes). The DNase-sensitive extra cellular substance with optical density (OD) at $260 \mathrm{~nm}$ and extinction coefficients $260 / 230$ and 260/280 $\approx 2$ accepted as free endogenous DNA expected to be the primer for the TdT enzyme. The polymeric substances with abnormal extinction coefficients $260 / 230$ and $260 / 280$ classify as a nucleoid. The concentration of free endogenous DNA evaluates as $1 \mu \mathrm{g}=0.02 \mathrm{OD} / \mathrm{cm}$ of the optical length.

Detection of spontaneous extracellular TdT-activity as result of template-independent monomer's polymerization with endogenous primers performers after the addition into $\mathrm{CM}$ of $5 \times 10^{-7} \mathrm{M}$ single substrate (deoxyguanosine triphosphate labeled by tritium $\left[8{ }^{3} \mathrm{H}\right] \mathrm{dGTP}, 1.3 \mathrm{Ci} / \mathrm{mmol}$; Perkin Elmer) for 15 60 minutes at $37^{\circ} \mathrm{C}$. After DEAE chromatography, the radioactivity of $\mathrm{CM}$ fractions collects on MF-Millipore Membrane Filter, 0.22/0.45 $\mu \mathrm{m}$ (Merck), washes, dries, and such samples measured in $10 \mathrm{ml}$ scintillation fluid (Ultima Gold, Perkin Elmer, USA) (Hionic Fluor, Packard) by spectrometer Hidex 300SL, Finland) with effectiveness around $17 \%$. Then, a nucleoid's radioactivity infraction normalizes to free DNA found in it by parallel DNase I-analyses.

\subsection{Preparation of Exogenous Labeled DNA and Its Uptake by Cells}

The exogenous chicken DNA (Reanal, Hungary) were labeled with tritium $\left({ }^{3} \mathrm{H}-\right.$ 
DNA) by the method of isotopic exchange between hydrogen at C- 8 of purine bases of the polymer and hydrogen of heavy-tritium (T)-water (THO) [12] in our modification [13] to simulate a possible biological activity of DNA-like byproducts of TdT in CM. Tritium-labeled DNA had a specific radioactivity of about $410 \mathrm{dpm} / \mu \mathrm{g}$ (i.e., about $60.4 \mu \mathrm{Ci} / \mathrm{mmol}$ of nucleotides).

Fragmentation of exogenous DNA, if needs, before use was performed in HBSS (Gibco) by ultrasonic set URSK-7H (NE Bauman's Moscow Higher Technical School, Russia) at resonance frequency $26.5 \mathrm{kHz}$ adjusting the exposure time under the control of DEAE-chromatography.

During incubation of cells $\left(2.7 \times 10^{7} / \mathrm{mL}\right)$ with prepared ${ }^{3} \mathrm{H}$-DNA $(2.5 \mu \mathrm{g} / \mathrm{mL})$ in Hanks solution for 120 minutes at $37^{\circ} \mathrm{C}$ and constant mixing, aliquot samples of cells, if they were, washes three times with Hanks solution, leases in sodium dodecyl sulfate buffer [14]. DNA isolates by well-recognized method Schmidt and Thangauser [15], and its radioactivity counts with beta-spectrometer Liquimat 220, Picker-Nuclear, USA, as described [13].

\subsection{Influence of Extra Cellular DNA on Spontaneous (Not Stimulated) DNA Synthesis in Cells}

Spontaneous (non-stimulated) DNA synthesis in intact and irradiated in vivo cells 6 hours after exposure $\left(2.7 \times 10^{7}\right.$ cells $/ \mathrm{mL}$ of Hanks solution $)$ controls by the joint incubation with labeled methyl- ${ }^{3} \mathrm{H}$ thymidine $\left({ }^{3} \mathrm{H}-\mathrm{TdR}, 26 \mathrm{Ci} / \mathrm{mmol}, 0.8\right.$ $\mu \mathrm{g} / \mathrm{mL}$; MP Biomedicals, Fisher Scientific) during $115 \mathrm{~min}$ at $37^{\circ} \mathrm{C}$. The cellular DNA in aliquots was isolated, and its radioactivity was measured, as described above. In parallel, the experiment repeats with exogenous unlabelled DNA (2.5 $\mu \mathrm{g} / \mathrm{mL}$ ) added by the 55 th minute of incubation.

\subsection{Statistical Analyses}

Single parameters were evaluated statistically with the calculation of an average, Standard Deviation (SD) and Standard Error (SE). The average values $M$ were compared using $t$-criterion and probability $p$. We described the trends of the aggregate parameters before and after sonication by mathematical functions generated automatically using non-linear approximations in the Excel program.

The coefficient determination $R^{2}$ used as a statistical measure of the goodness of fit of the regression line to the data. Satisfactory $R^{2}$ values were confirmed using Equation (1) for $t$-parameter:

$$
t=\sqrt{R^{2} \times(n-2) /\left(1-R^{2}\right)}
$$

\section{Results}

Figure 1 shows the extracellular nucleoid in conditioned media (CM) of normal and injured thymocytes CM of normal cells obtained from intact animals after shame-irradiation (a) as well as CM since 0.5 (b) and 6 hours after irradiation (c) have the different fractions of nucleoid with absorption at $260 \mathrm{~nm}$ wavelength. DNase-sensitive parts of nucleoid are free DNA. Application only in lower the 


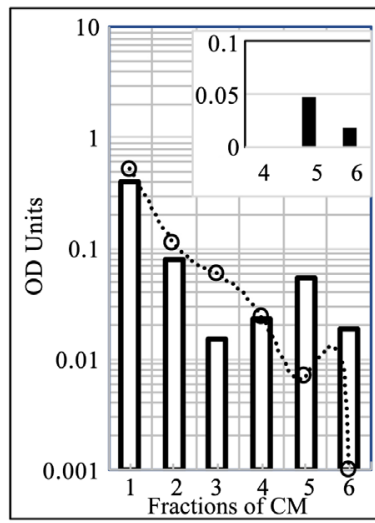

(a)

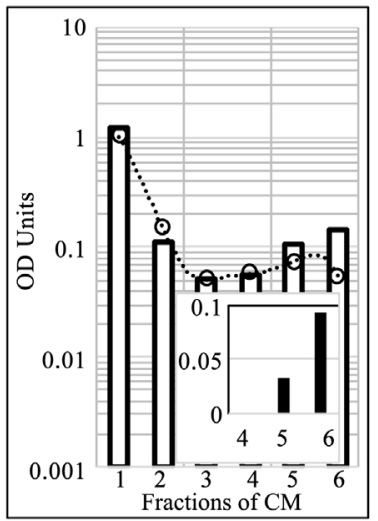

(b)

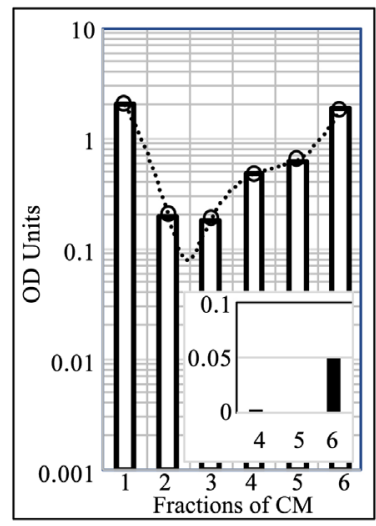

(c)

Figure 1. The extracellular nucleoid in thymocytes' CM from animals sacrificed before (a), since 0.5 (b), and 6 hours (c) after single total body X-irradiation of rats at dose 8 Gy. Abscissa: ascending numbers of DNA-like fractions with average molecular weight $(\mathrm{Mw})$ $5 \times 10^{2}, 2 \times 10^{3}, 5 \times 10^{4}, 1 \times 10^{5}, 1 \times 10^{6}$, and $5 \times 10^{6}$ Daltons, according to a CM' fractionation on DEAE-paper. Ordinate: Units of Optical Density (OD Units) at $260 \mathrm{~nm}$ received at $4 \mathrm{~cm}$ of optical length. Columns-base data before DNase treatment. Circles with dotted lines-the data after DNase treatment. Columns' data satisfy only one or none of two additional ratios (OD260/OD230 $\geq 2$ and OD260/OD230 $\geq 2$ ) that are typical for free double strand DNA (i.e., these fractions include proteins and monomers of DNA like bases, nucleoside, nucleotides, and their deoxynucleic forms). The pure DNase-sensitive DNA in fractions shown in the boxes like black columns.

average quantities of such DNA were $0.825,1.55$, and $0.665 \mu \mathrm{g} / \mathrm{ml}$ for normal, and injured cells by 0.5 and 6 hours correspondently. They associate mostly with fraction $5\left(1 \times 10^{6} \mathrm{Da}\right)$ before irradiation and fractions $6\left(5 \times 10^{6} \mathrm{Da}\right)$ after it, presenting potential primers for enzyme before, 0.5 , and 6 hours after irradiation $\left(\approx 8.3 \times 10^{-1}, 3.1 \times 10^{-1}\right.$, and $\left.1.3 \times 10^{-1} \mathrm{pmol} \mathrm{DNA} / \mathrm{mL}\right)$.

Figure 2 shows the kinetics of spontaneous polymerization of ${ }^{3} \mathrm{H}-\mathrm{dTTP}$ on endogenous DNA-primers of CM by (a) time of incubation (minutes), by (b) concentration of DNase-sensitive DNA in CM $(\mu \mathrm{g} / \mathrm{mL})$ without cells in CM (b), and in the presence of them (c).

Taking into account the specific activity of ${ }^{3} \mathrm{H}$-dTTP $(1.3 \mathrm{Ci} / \mathrm{mmol})$ and effectiveness of counting (17\%), the polymerization's activity of $\mathrm{TdT}$ in $\mathrm{CM}$ were $1.18,0.080,5.66 \mathrm{pmol} / \mathrm{mL}$ without cells, and $0.316,0.036,0.328 \mathrm{pmole} / \mathrm{ml}$ with them for before and $0.5,6$ hours after radiation exposure. Then, the cells uptake 0.864 and $0.044,5.33$ pmoles were with effectiveness $76 \%, 53 \%$, and $92 \%$ before, 0.5 , and 6 hours after irradiation correspondently (dotted line in Figure 2(c)).

The effectiveness of the uptake of labeled enzyme's product by cells depends on the numbers of labeled primers-molecules, in pmoles, but opposes to it bulk quantity of DNA-primers, in $\mu$ g (Figure $2(\mathrm{c})$ ). None of the relation of uptake's effectiveness with the unlabeled primers in pmoles, as well as nucleoid's concentration in terms of absorption at $260 \mathrm{~nm}$ wavelength were found. These data point mainly to the consumption of the labeled products after their selective separation from nucleoids, i.e. in the form of free polymers. 


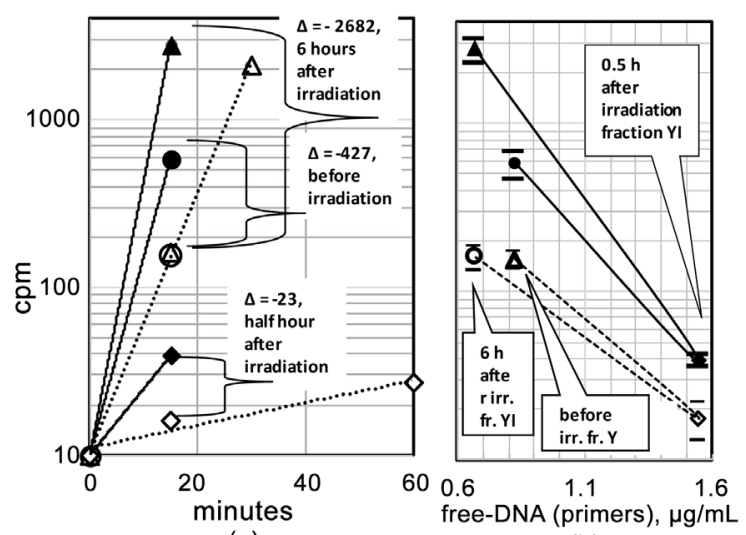

(a)

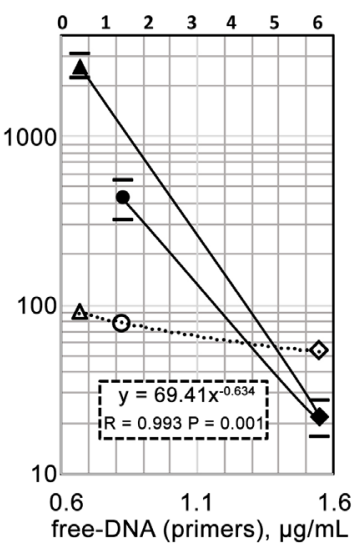

(c)

Figure 2. The polymerization of ${ }^{3} \mathrm{H}$-dTTP on extracellular DNA-primer in CM of thymocytes from animals sacrificed before (circles), since a 0.5 hour (rhombuses) and 6 hours after (triangles) single total body X-irradiation of rats at dose 8 Gy. Abscissa: (a) time of incubation at $37^{\circ} \mathrm{C}$, minutes. (b) and (c) quantity of a DNase-sensitive DNA (free-DNA) in the fractions of nucleoid found by the spectrophotometry and DNase analysis in CM, $\mu \mathrm{g} / \mathrm{mL}$. Ordinate: (a), (b) radioactivity of a free DNA-fractions (number 5 and 6) of CM after 15 minutes of incubation, cpm. Dark symbols-CM without cells (WO), white symbols-CM with them (W); (c, black symbols) radioactivity of a free DNA captured by cells as a difference between WO and W results; (c, white symbols, dotted line) effectiveness of a capture as a ratio $(\mathrm{WO}-\mathrm{W}) / \mathrm{W}$ results, $\%$.

Figure 3(a) shows the artificial uptake of pure exogenous DNA (average Mw $\approx 4.5 \times 10^{6}$ and $\left.1.5 \times 10^{5} \mathrm{Da}\right)$ by intact cells from extracellular media $(6 \mu \mathrm{g} / \mathrm{mL}$, i.e. $\approx 1.3 \mathrm{pmol} / \mathrm{mL}$ of polymeric molecules and $\approx 40 \mathrm{pmole} / \mathrm{mL}$ of fragmented ones).

According to Figure 3(a), the uptake reaches $0.48-0.55 \mu \mathrm{g}$ by maximums, i.e. only $\approx 8 \%-9 \%$ of the extracellular amount, independently of the difference of Mw. But the number of captured molecules of polymeric DNA $\left(1 \times 10^{-1} \mathrm{pmol}\right)$ is significantly less than the fragmented one $(3.6 \mathrm{pmol})$. It is remarkable that the longer the time of conditioning the extracellular media is, the less the quantity of captured DNA is registered (Figure 3(a)). It is a sign of the wholeness of the uptake, i.e., an intracellular equilibrium between polymeric (acid-insoluble, reutilized) and degraded (acid-soluble) forms.

According to Figure $3(\mathrm{c})$, the transfer $(\Delta 90)$ of exogenous DNA from media into cells 6 hours after their irradiation $\left(8.7 \%, 1.1 \times 10^{-1}\right.$ pmole $)$ is comparable with that for intact cells $\left(6.1 \%, 7.9 \times 10^{-2} \mathrm{pmol}\right)$ in Figure $3(\mathrm{~b})$. Thus, data $3 \mathrm{~b}$ and $3 \mathrm{c}$ proof the ability of cells to consume large amounts of free DNA from extracellular space.

Does the template-free extracellular polymerization of deoxinucleotides, on the one hand, and consumption of the polymeric forms of DNA by cells, on the other hand, affect the viability of the cells, being the steps of a common mechanism?

Figure 4(a) shows that the low viability of cells at low concentration can be improved by conditioned media up to the level typical for cells suspension concentrated more than a hundredfold. 


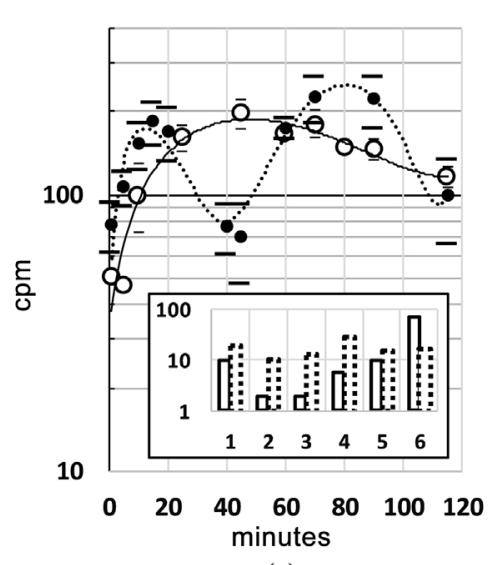

(a)

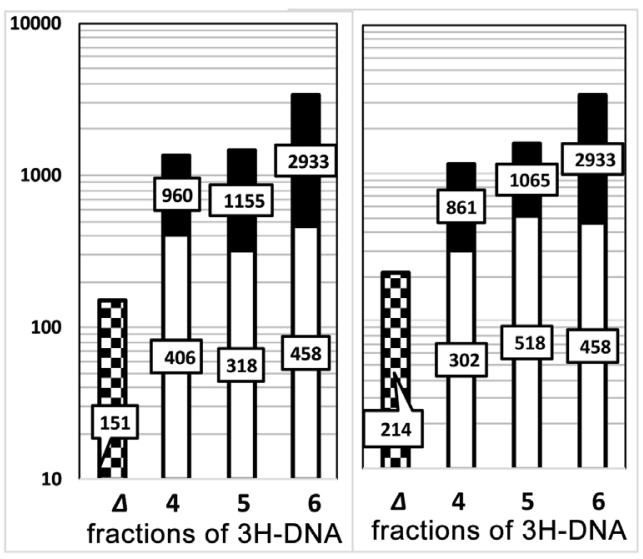

(b)

(c)

Figure 3. The uptake of exogenous $3 \mathrm{H}-\mathrm{DNA}(6 \mu \mathrm{g} / \mathrm{ml})$ by thymocytes $\left(2.5 \times 10^{7} / \mathrm{mL}\right)$ from conditioned media (a) and spontaneous fragmentation of 3H-DNA outside the sells by 90th minute of incubation. Abscissa: (a) time of incubation of exogenous DNA with intact cells, minutes; (b) and (c) DEAE-fractions of ${ }^{3} \mathrm{H}$-DNA in conditioned media for intact cells (b) and cells 6 hours after their irradiation in vivo (c). White and black columns-fractions 5 and 6 correspondently, other fractions are not shown; B-original ${ }^{3} \mathrm{H}$-DNA before incubation ( $\mathrm{Mw} \approx 4.5 \times 10^{6} \mathrm{Da}$ ), WO and $\mathrm{W}-{ }^{3} \mathrm{H}-\mathrm{DNA}$ by 90 th minute of incubation in media without cells (WO) or with them (W); $\Delta$-total ${ }^{3} \mathrm{H}$-DNA captured by cells by 90th minute of the incubation. Ordinate: (a) radioactivity of acid-insoluble fraction of cells' DNA, cpm. In the box: solid line-fractions of original (before incubation) ${ }^{3} \mathrm{H}$-DNA $\left(\mathrm{Mw} \approx 4.5 \times 10^{6} \mathrm{Da}\right)$, dotted line-original ${ }^{3} \mathrm{H}$-DNA after preliminary fragmentation (M.w. $\approx 1.5 \times 10^{5} \mathrm{Da}$ ), \% in the media. (b) and (c) radioactivity of DEAE-fractions of labeled exogenous DNA in CM by 90th minute of incubation, cpm in white boxes. Patterned columns-the part of the total labeled DNA captured by cells: $\Delta_{90}=\mathrm{cpm}_{\mathrm{WO}}-$ $\mathrm{cpm}_{\mathrm{W}}$.

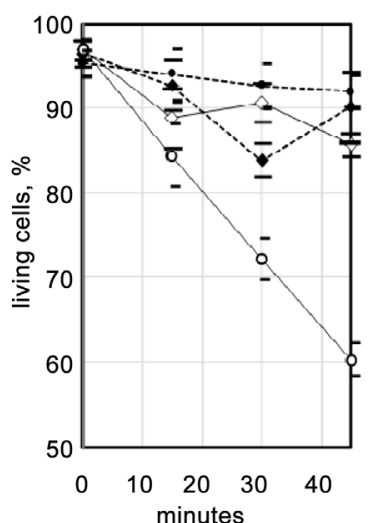

(a)

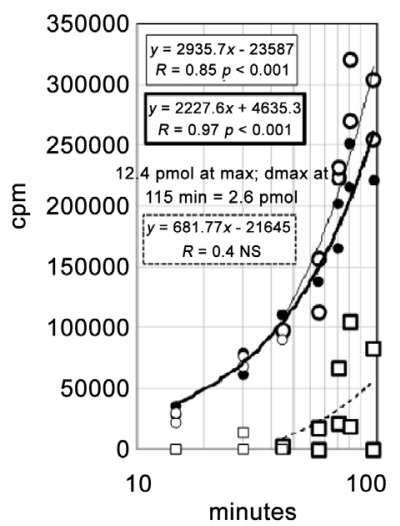

(b)

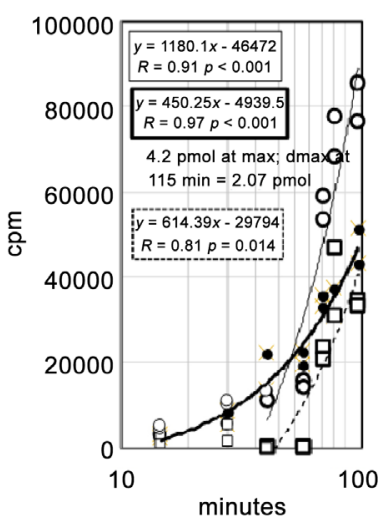

(c)

Figure 4. Phenomenon of thymocyte's CM (a) and its simulation with exogenous unlabeled DNA (b) and (c). Abscissa: ((a), (b), (c)) time of incubation, minutes. Ordinate: (a) cells viability, \%; circles-unconditioned media (control), rhombuses-preliminary Conditioned Media $(\mathrm{CM})$ by $2 \times 10^{7}$ irradiated cells $/ \mathrm{mL}$; white symbols- $1 \times 10^{5}$ cells $/ \mathrm{mL}$, black symbols- $2 \times 10^{7}$ cells $/ \mathrm{mL}$; (b) and (c)) radioactivity of ${ }^{3} \mathrm{H}-\mathrm{TdR}$ incorporated into cellular DNA (acid-insoluble fraction). (b)-intact cells, (c)-irradiated in vivo cells; thick solid lines-without exogenous DNA, thin solid lines-fragmented DNA, added by 45 th minute of incubation; dotted lines-additional ${ }^{3} \mathrm{H}$-TdR' uptake in the presence of exogenous DNA. The approximating equations are in the boxes with corresponding line's characters. 
A low level of ${ }^{3} \mathrm{H}-\mathrm{TdR}$ incorporation is typical for irradiated cells (Figure 4(c)). Only for them, the small amounts of exogenous DNA added to media can increase the ${ }^{3} \mathrm{H}$-TdR uptake by cells significantly. The reproducing similar phenomenon with intact cells is impossible, though the same cell concentration (Figure 4(b)).

\section{Discussion}

Intracellular synthesis of dNTP is not autonomy, because missing metabolites or precursors can be imported into cells from neighboring cells or hemolymph. The mechanisms of such a rescue are uncovered [16].

The deficit of the intracellular pool of dNTP in the normal, embryonic and malignant tissues limits strongly cells proliferation via arrest the cycle in S-phase [17] [18]. The six hours after irradiation covers the phenomenon of reversible arrest in cell cycle progression, which is lasting about an hour for every 1 Gy delivered and resulting in a reduced mitotic index [19]. This time corresponds in situ to linear increasing of apoptotic cells number in irradiated gland from $0.8 \%$ - $1.8 \%$ to $3 \%-11 \%$ [20], which accompanies by increasing of single-strand breaks (SSB) of cellular DNA [21].

Quick SSB repair by intracellular DNA-polymerase is completed as early as 1 0.75 hours after irradiation [22]. The chromatin of rat thymocytes selected 6 hours after total body irradiation, is already cleaved but has still not been eliminated, as one supposed [23]. Therefore, the maximal level of the high polymeric, acid-insoluble nucleoid in the media (Figure 1) appears in vitro due to the cell's decay at the time of conditioning of CM.

Simultaneously, the maximal concentration of bulk optically active acid-soluble short fractions of nucleoid number 1 increase plainly from control level to 0.5 and 6 hours after irradiation, reflecting the destruction of dead cells during conditioning, which may deliver into CM around $100-120$ pmol of dNTP per one million lysing cells [24] [25]. Accordingly, at real 6\% - 8\% apoptotic death of 2.3 $\times 10^{8}$ thymocytes $/ \mathrm{ml}$, a maximal amount of endogenous $\mathrm{dNTP}$ can reach around $2 \mathrm{nmol} / \mathrm{mL}\left(2 \times 10^{-6} \mathrm{M}\right)$ in CM [19]. This amount of substrates is quite compatible with the average natural concentration of precursors of DNA synthesis in plasma and other extracellular fluids (the range of $0.4-6 \mu \mathrm{M}$ ) [18].

However, phosphorylating precursors, being negatively charged, are disable penetrate negatively charged cells membrane. One of the possible transporters of needed phosphorylated metabolites inside the cells is pinocytosis, can be thought of as an equal-opportunity importer. It contains surrounding extracellular fluid along with biopolymers and any negatively charged deoxinucleotides into membrane vesicles and imports them easily [26]. The TdT enzyme may be a link in this pathway, leading to restore the intracellular pools of deoxinucleotides and rescue the spontaneous death of young lymphocytes [27]. They migrated into target organs and tissues as lymphoid progenitors with morphogenic (trophic) function [28]. If to consider their apoptosis as physiological suicide (i.e. holocrine 
type of secretion), then cell-free DNA-primers [29] and TdT enzyme delivered in extracellular media can convert single extracellular deoxynucleotides into oligomers which are captured by neighboring cells, especially if they injured and needed in quick replenishment of exhausted pool of the phosphorylated precursors. Such transfer pinocytosis of blocking precursors is more effective than separated/single ones.

Apart from this general mechanism, the more specific function of TdT might be expected too. Among four deoxynucleosides triphosphate (dNTP), the concentrations of dGTP in dividing cells are $5-8$ fold lower than in tree others dATP, dCTP, and dTTP [18] [25] [30]. Surprisingly, the preferred order of incorporation by TdT is dGTP $>$ dCTP $>$ dTTP $>$ dATP [31], seeming as a process for compensation of intracellular deficit of dGTP. Tight control of the dNTP pool is essential for cellular homeostasis, especially for deoxyguanosine nucleotides during radiation [32] or chemical damages, for example, the therapeutic toxicant gemcitabine [33]. The deficit dGMP in lymphoid cells follows oxidative stress of different origins when the excess of reactive oxygen species (ROS) modifies normal precourses into mutagen 8-Oxo-7,8-dihydro-2-deoxyguanosine (8-oxo-dG). 8-oxo$\mathrm{dG}$ is removed from the polymer by base excision repair and is excreted into the extracellular environment [34] [35].

Generally recognized the only intracellular function, as noted in the introduction, does not explain several biological features of $\mathrm{TdT}^{+}$cells. Another forgotten but mysterious property of $\mathrm{TdT}^{+}$lymphocytes is their mass and speed emigration from the gland in response to the somatic injury remoted distantly.

In parallel with artificial lymphocytopenia performed by extracorporeal irradiation of circulating blood, 55\% of the TdT-positive cortical thymocytes leaves intact gland during 6 hours remotely. The speed of such devastation is highest: fifth-fold faster than the white pulp cells of intact spleen along with yet unchangeable pools of lymph nodes. Thus, by 6 hours after irradiation thymus cells population contains the excess of resistible and slowly mobilizable lymphocytes in medullae though the $45 \%$ of rest cortical cells and, probably, the resident progenitors coming from bone marrow, start already the repopulation of the devastated cortex [36].

\section{Conclusions}

Though the functional outcome of the $\mathrm{TdT}^{+}$cells emigration looks nonsense in the view of intrathymic providing a variety of antigen receptors at the $\mathrm{V}(\mathrm{D}) \mathrm{J}$ junction of gene segment, the feeding/morphogenic function of these circulating cells for renewing the other tissues and organs seems logical. It follows from the property of TdT-positive young emigrating lymphocytes to achieve the other tissues and organs, dies via apoptosis/suicide/holocrine secretion, and take part in the renewing tissues of different histological types [37].

Future studies will undoubtedly shed more insight into the biological role and molecular mechanisms of young lymphocytes transient in different tissues of a body. 


\section{Acknowledgements}

Aleksei N. Shoutko thanks the Ministry of Health Care of Russian Federation for financial support of this research.

\section{Conflicts of Interest}

The author declares no conflicts of interest regarding the publication of this paper.

\section{References}

[1] Azouna, N.B., Berraeis, L., Regaya, Z. and Jenhani, F. (2011) Immunophenotyping of Hematopoietic Progenitor Cells: Comparison between Cord Blood and Adult Mobilized Blood Grafts. World Journal of Stem Cells, 3, 104-112. https://doi.org/10.4252/wjsc.v3.i11.104

[2] Srivastava, B.I.S. (1974) Deoxynucleotide-Polymerizing Enzymes in Normal and Malignant Human Cells. Cancer Research, 34, 1015-1026.

[3] Haruna, T. and Atsushi, T. (2019) Age-Dependent Modification of Intracellular $\mathrm{Zn}^{2+}$ Buffering in the Hippocampus and Its Impact. Biological and Pharmaceutical Bulletin, 42, 1070-1075. https://doi.org/10.1248/bpb.b18-00631

[4] Spigelman, Z., Duff, R., Beardsley, G.P., Broder, S., Cooney, D., Landau, N.R., et al. (1988) 2',3'-Dideoxyadenosine Is Selectively Toxic for TdT-Positive Cells. Blood, 71, 1601-1608. https://doi.org/10.1182/blood.V71.6.1601.1601

[5] Zhang, Y., Shi, M., Wen, Q., Luo, W., Yang, Z., Zhou, M., et al. (2012) Antigenic Stimulation Induces Recombination Activating Gene 1 and Terminal Deoxynucleotidyl Transferase Expression in a Murine T-Cell Hybridoma. Cellular Immunology, 274, 19-25. https://doi.org/10.1016/j.cellimm.2012.02.008

[6] McElhinny, S.A.N. and Ramsden, D.A. (2003) Polymerase Mu Is a DNA-Directed DNA/RNA Polymerase. Molecular and Cellular Biology, 23, 2309-2315. https://doi.org/10.1128/MCB.23.7.2309-2315.2003

[7] Motea, E.A. and Berdis, A.J. (2010) Terminal Deoxynucleotidyl Transferase: The Story of a Misguided DNA Polymerase. Biochimica et Biophysica Acta (BBA)-Proteins and Proteomics, 1804, 1151-1166. https://doi.org/10.1016/j.bbapap.2009.06.030

[8] Nagler, M., Insam, H., Pietramellara, G. and Ascher-Jenull, J. (2018) Extracellular DNA in Natural Environments: Features, Relevance and Applications. Applied Microbiology and Biotechnology, 102, 6343-6356.

https://doi.org/10.1007/s00253-018-9120-4

[9] Zhivotovsky, B. (2020) Programmed Cell Death: Historical Notes from Russia. Biochemistry (Moscow), 85, 1127-1133. https://doi.org/10.1134/S0006297920100016

[10] Sheehy, E.J., Vinardell, T., Toner, M.E., Buckley, C.T. and Kelly, D.J. (2014) Altering the Architecture of Tissue Engineered Hypertrophic Cartilaginous Grafts Facilitates Vascularisation and Accelerates Mineralisation. PLOS ONE, 9, e90716. https://doi.org/10.1371/journal.pone.0090716

[11] Davila, C. and Charles, P. (1965) The Chromatography of Nucleic Acid Preparations on Deae-Cellulose Paper: I. Fractionation of Deoxyribonucleic Acid on Paper Strips or Centrifuged Paper Pulp. Journal of Chromatography A, 19, 382-395. https://doi.org/10.1016/S0021-9673(01)99474-9

[12] Doppler-Bernardi, F. and Felsenfeld, G. (1969) In Vitro Incorporation of Tritium into Native DNA. Biopolymers, 8, 733-741. https://doi.org/10.1002/bip.1969.360080604

[13] Shutko, A.N. and Shatinina, N.N. (1974) Effect of the Degree of Polymerization of 
Exogenous DNA on Its Incorporation into Rat Thymocytes in Vitro. Bulletin of EXperimental Biology and Medicine, 77, 269-271. https://doi.org/10.1007/BF00802476

[14] Sefton, B.M. (2001) Labeling Cultured Cells with ${ }^{32} \mathrm{P}_{\mathrm{i}}$ and Preparing Cell Lysates for Immunoprecipitation. Current Protocols in Protein Science, 10, 13.2.1-13.2.8. https://doi.org/10.1002/0471140864.ps1302s10

[15] Shutko, A.N., Shatinina, N.N. and Rakitianskaia, I.A. (1983) Role of Terminal Deoxyribonucleotidyl Transferase in Stimulating Lymphocyte DNA Synthesis as Affected by PHA. Tsitologiia, 25, 1212-1215. (In Russian)

[16] Liu, B. and Großhans, J. (2019) The Role of dNTP Metabolites in Control of the Embryonic Cell Cycle. Cell Cycle, 18, 2817-2827.

https://doi.org/10.1080/15384101.2019.1665948

[17] Kohnken, R., Kodigepalli, K.M. and Wu, L. (2015) Regulation of Deoxynucleotide Metabolism in Cancer: Novel Mechanisms and Therapeutic Implications. Molecular Cancer, 14, Article No. 176. https://doi.org/10.1186/s12943-015-0446-6

[18] Traut, T.W. (1994) Physiological Concentrations of Purines and Pyrimidines. Molecular and Cellular Biochemistry, 140, 1-22. https://doi.org/10.1007/BF00928361

[19] Malkinson, F.D. (1981) Some Principles of Radiobiology: A Selective Review. Journal of Investigative Dermatology, 76, 32-38.

https://doi.org/10.1111/1523-1747.ep12479220

[20] Fujita, K., Kawarada, Y., Terada, K., Sugiyama, T., Ohyama, H. and Yamada, T. (2000) Quantitative Detection of Apoptotic Thymocytes in Low-Dose X-Irradiated Mice by an Anti-Single-Stranded DNA Antibody. Journal of Radiation Research, 41, 139-149. https://doi.org/10.1269/jrr.41.139

[21] Ivannik, B.P., Golubeva, R.V., Proskuryakov, S.Y. and Ryabchenko, N.J. (1975) Repair and Degradation of DNA in the Irradiated Rat Thymocytes. Radiobiologiya, 15, 500-505. (Article in Russian)

[22] Tempel, K. (1990) Changes in Nucleoid Viscosity Following X-Irradiation of Rat Thymic and Splenic Cells in Vitro. Radiation and Environmental Biophysics, 29, 19-30. https://doi.org/10.1007/BF01211232

[23] Pechatnikov, V.A., Afanasyev, V.N., Korol, B.A., Korneev, V.N., Rochev, Yu.A. and Umansky, S.R. (1986) Flow Cytometry Analysis of DNA Degradation in Thymocytes of y-Irradiated or Hydrocortisone Treated Rats. General Physiology and Biophysics, 5, 273-284.

[24] Qiu, X., Guittet, O., Mingoes, C., El Banna, N., Huang, M.-E., Lepoivre, M. et al. (2019) Quantification of Cellular Deoxyribonucleoside Triphosphates by Rolling Circle Amplification and Förster Resonance Energy Transfer. Analytical Chemistry, 91, 1456114568. https://doi.org/10.1021/acs.analchem.9b03624

[25] Huang, C.-Y., Yagüe-Capilla, M., González-Pacanowska, D. and Chang, Z.-F. (2020) Quantitation of Deoxynucleoside Triphosphates by Click Reactions. Scientific Reports, 10, Article No. 611. https://doi.org/10.1038/s41598-020-57463-3

[26] Desai, A.S., Hunter, M.R. and Kapustin, A.N. (2019) Using Macropinocytosis for Intracellular Delivery of Therapeutic Nucleic Acids to Tumor Cells. Philosophical Transactions of the Royal Society B, Biological Sciences, 314, Article ID: 20180156. https://doi.org/10.1098/rstb.2018.0156

[27] Mann, C.L., Hughes, F.M. and Cidlowski, J.A. (2000) Delineation of the Signaling Pathways Involved in Glucocorticoid-Induced and Spontaneous Apoptosis of Rat Thymocytes. Endocrinology, 141, 528-538. https://doi.org/10.1210/endo.141.2.7314

[28] Shoutko, A.N., Gerasimova, O.A., Fedorov, V.A. and Zherebtsov, F.K. (2019) NonInvasive Vibration-Stress of the Cirrhotic Liver of Patients Waiting for Transplantation Induces of Circulating CD133+ Stem Lymphocytes Committed Phenotypi- 
cally toward the Liver. Open Journal of Biophysics, 9, 155-168.

https://doi.org/10.4236/ojbiphy.2019.93012

[29] Hu, Z., Chen, H., Long, Y., Li, P. and Gu, Y. (2021) The Main Sources of Circulating Cell-Free DNA: Apoptosis, Necrosis and Active Secretion. Critical Reviews in Oncology/ Hematology, 157, Article ID: 103166.

https://doi.org/10.1016/j.critrevonc.2020.103166

[30] Ferraro, P., Pontarin, G., Crocco, L., Fabris, S., Reichard, P. and Bianchi V. (2005) Mitochondrial Deoxynucleotide Pools in Quiescent Fibroblasts. A Possible Model for Mitochondrial Neurogastrointestinal Encephalomyopathy (MNGIE). The Journal of Biological Chemistry, 280, 24472-24480. https://doi.org/10.1074/jbc.M502869200

[31] Deshpandea, S., Yangb, Y., Chilkotia, A. and Zauschera, S. (2019) Enzymatic Synthesis and Modification of High Molecular Weight DNA Using Terminal Deoxynucleotidyl Transferase. Methods in Enzymology, 627, 163-188. https://doi.org/10.1016/bs.mie.2019.07.044

[32] Belli, M. and Tabocchini, M.A. (2020) Ionizing Radiation-Induced Epigenetic Modifications and Their Relevance to Radiation Protection. International Journal of Molecular Sciences, 21, Article No. 5993. https://doi.org/10.3390/ijms21175993

[33] Guo, J.-R., Chen, Q.-Q., Lam, C.W.K., Wang, C.-Y., Wong, V., K.W., Chang, Z.-F., et al. (2016) Profiling Ribonucleotide and Deoxyribonucleotide Pools Perturbed by Gemcitabine in Human Non-Small Cell Lung Cancer Cells. Scientific Reports, 6, Article No. 37250. https://doi.org/10.1038/srep37250

[34] Haghdoost, S., Czene, S., Näslund, I., Skog, S. and Harms-Ringdahl, M. (2005) Extracellular 8-oxo-dG as a Sensitive Parameter for Oxidative Stress in Vivo and in Vitro. Free Radical Research, 39, 153-162. https://doi.org/10.1080/10715760500043132

[35] Sangsuwan, T. and Haghdoost, S. (2008) The Nucleotide Pool, a Target for Low-Dose $\gamma$-Ray-Induced Oxidative Stress. Radiation Research, 170, 776-783.

[36] Cronkite, E.P., Chanana, A.D., Joel, D.D., Rai, K.R. and Schiffer, L.M. (1968) Influence of Extracorporeal Irradiation of the Blood and Lymph on Lymphopoiesis and Immunity. Proceedings of a Symposium on the Effects of Radiation on Cellular Proliferation and Differentiation, Monaco, 1-5 April 1968, 307-326.

[37] Shoutko, A.N. (2019) Immunity or Morphogenesis in Cancer Development and Treatment. Integrative Cancer Science and Therapeutics, 6, 1-8.

https://doi.org/10.15761/ICST.1000317 